\title{
Sources, speciation and transformation of arsenic in the gold mining impacted Jiehe River, China
}

\author{
Yongbing Cai ${ }^{\text {a, b }}$, Hua Zhang ${ }^{\text {b, * }}$, Guodong Yuan ${ }^{\text {b }}$, Feiyue Li ${ }^{\text {a }}$ \\ ${ }^{a}$ College of Resource and Environment, Anhui Science and Technology University, Anhui 233100, China \\ ${ }^{\mathrm{b}}$ Key Laboratory of Coastal Environmental Processes and Ecological Remediation, Yantai Institute of Coastal Zone Research, Chinese Academy of Sciences, \\ Shandong 264003, China
}

\section{A R T I C L E I N F O}

\section{Article history:}

Received 24 March 2017

Received in revised form

29 June 2017

Accepted 3 July 2017

Available online 4 July 2017

Editorial handling by Huaming Guo.

\section{Keywords:}

Gold mining

Arsenic

Iron

Colloid

Modeling

\begin{abstract}
A B S T R A C T
Mining-contaminated waters may contain high levels of arsenic (As) and iron (Fe), among various metals and metalloids. The complex behavior of As makes its contamination difficult to remediate. This study aimed to determine the sources, possible association of As and Fe with colloids and their speciation and mobility in the Jiehe River, a stream impacted by gold mining. Particulate $(>450 \mathrm{~nm})$, colloidal $(7$ $-450 \mathrm{~nm}$ ), and truely dissolved $(<7 \mathrm{~nm}$ ) forms of As and Fe were determined, and the species of As [As(III), As(V), monomethylarsonic acid, and dimethylarsinic acid] and $\mathrm{Fe}$ [Fe(II) and $\mathrm{Fe}(\mathrm{III})]$ were both analyzed and modelled using geochemical program Visual MinteQ 3.0. High concentrations of As and Fe were observed in both filtered and particulate forms in most of the water samples. Total As was in the range of $1.0-719 \mu \mathrm{g} \mathrm{L}^{-1}$ with a median of $140 \mu \mathrm{g} \mathrm{L} \mathrm{L}^{-1}$. Total Fe was $0.4-68.2 \mathrm{mg} \mathrm{L}^{-1}$ with a median of $15.0 \mathrm{mg} \mathrm{L}^{-1}$. Arsenic was mainly adsorbed on ferrihydrite, goethite, and hematite in the upstream water samples. In contrast, it was mostly in truely dissolved forms in the water samples at downstream. Visual MinteQ 3.0 modelling results revealed that As adsorbed on, or co-precipitated with, stream sediment can be easily released under the environmental conditions of the downstream reach $(11.4-37.5 \mathrm{~km})$. These findings would benefit the environmental management of gold mining impacted Jiehe River, and indicate the need for further quantitative research on As migration facilitated by Fe (hydr)oxide colloids and the release of As from contaminated stream sediments.
\end{abstract}

() 2017 Elsevier Ltd. All rights reserved.

\section{Introduction}

Mining and smelting operations have altered the natural distribution and occurrence of metals and metalloids on the surface of the Earth (Rauch, 2012). Their release into aquatic and terrestrial environments is a potential threat to environmental and human health. Being toxic and carcinogenic, arsenic release via acid mine drainage (Desbarats et al., 2015; Basu and Schreiber, 2013) and the elevated concentrations in waters, soils, and sediments are of particular concern.

As is produced from the oxidation of arsenian pyrite, such as arsenopyrite (FeAsS) (Paikaray, 2015). Its mobility is controlled by adsorption to, or co-precipitation with, oxide substrates, including aluminum ( $\mathrm{Al}$ ), iron (Fe), and manganese ( $\mathrm{Mn}$ ) hydroxides (Carroll et al., 2002). Sediment acts either as a sink for As, keeping its

\footnotetext{
* Corresponding author.

E-mail address: hzhang@yic.ac.cn (H. Zhang).
}

concentration in water low, or as a source of As, releasing it into water and making water quality below environmental standards for a long period of time (Linge, 2008; Varol, 2011; Equeenuddin et al., 2013).

The behavior of As is further complicated because it occurs in two oxidation states $(+3$ and +5$)$ and exists in both inorganic species, e.g., $\mathrm{As}(\mathrm{III})$ and $\mathrm{As}(\mathrm{V})$, and organic species, e.g., monomethylarsonic (MMA) and dimethylarsinic (DMA) (Baeyens et al., 2007). In acid mine drainage (AMD)-contaminated areas, inorganic $\mathrm{As}(\mathrm{III})$ and $\mathrm{As}(\mathrm{V})$ dominate environments that contain oxidized sulfur species (Cheng et al., 2009). When AMD contains high concentrations of Fe its oxidation state affects As species (Frau et al., 2010).

When $\mathrm{pH}$ is increased, arsenic is rapidly scavenged through coprecipitation and adsorption onto Fe compounds (Frau et al., 2010). With a $\mathrm{pH}$ greater than $3.5, \mathrm{Fe}(\mathrm{II})$ is strongly susceptible to oxidation to $\mathrm{Fe}(\mathrm{III})$; and then $\mathrm{Fe}(\mathrm{III})$ precipitates as an oxyhydroxide or oxyhydroxysulfate, which may form mobile colloidal carriers for As (Cheng et al., 2009; Fritzsche et al., 2011). Earlier studies used 
synchrotron X-ray methods to characterize natural colloids and their association with As in mine systems (Slowey et al., 2007; Serrano et al., 2015). Slowey et al. (2007) described the transport of $\mathrm{As}(\mathrm{V})$ that was adsorbed onto colloidal ferrihydrite and jarosite in columns packed with mine tailings. As(V) can be easily adsorbed onto nanoparticulate ferrihydrite and transported downstream in a mine-impacted creek (Serrano et al., 2015).

The Jiehe River has been impacted by gold mining for centuries and it discharges into the Laizhou Bay. Elevated concentrations of $\mathrm{As}, \mathrm{Cr}, \mathrm{Pb}, \mathrm{Cd}, \mathrm{Cu}$, and $\mathrm{Zn}$ were observed in stream sediment along approximately $37.5 \mathrm{~km}$ of the Jiehe River (Zhang et al., 2014). Therefore, the stream sediment of the Jiehe River is a potential environmental threat and may be a secondary source of As in the aquatic system. However, data are scarce on As speciation and mobility in the Jiehe River where geochemistry conditions in the upstream and downstream reaches are different.

In this study, we analyzed As concentration, speciation, and mobility in water samples along the main stream reach of the Jiehe River. The occurrence of As was determined in the particulate, colloidal, and true dissolved forms. Taking into account the role of Fe chemistry in the speciation and transport of As, we conducted scanning electron microscopy-energy dispersive spectroscopy (SEM-EDS) analysis and geochemical modeling to reveal the environmental and geochemical behavior of As and its relationship to Fe-oxides. The study will provide essential information to assist effective remediation of As in the Jiehe River and other miningcontaminated streams.

\section{Materials and methods}

\subsection{Sampling area description}

The Jiehe River is located at the Zhao-Lai gold mineralization belt with a latitude of $37^{\circ} 05^{\prime}-37^{\circ} 33^{\prime} \mathrm{N}$ and a longitude of $120^{\circ} 08^{\prime}-120^{\circ} 38^{\prime} \mathrm{E}$. The headwaters of the river originate from the Luoshan Mountain, where the Linglong gold mine is located (Fig. 1). The Bujia, Chengdong, and Zhongliu rivers are three major tributaries, which all contribute to the main stream of the Jiehe River. The entire watershed is approximately $585 \mathrm{~km}^{2}$. The reach length of the Jiehe River is approximately $42 \mathrm{~km}$; it flows northwest into the Laizhou Bay of the Bohai Sea (Fig. 1). Detailed information about the Jiehe River can be found in Zhang et al. (2014).

The Zhao-Lai gold mineralization belt is the largest gold repository in China; it contains massive polymetallic sulfide deposits. Pyrite $\left(\mathrm{FeS}_{2}\right)$ is the main mineral in these deposits; in addition, there are lesser quantities of sphalerite $(\mathrm{ZnS})$, galena $(\mathrm{PbS})$, and chalcopyrite $\left(\mathrm{CuFeS}_{2}\right)$, as well as other sulfides that contain minor quantities of $\mathrm{Co}, \mathrm{Ni}, \mathrm{Cd}, \mathrm{Ag}$, and $\mathrm{Sn}$ (Shen et al., 2013). This area is well-known as the "gold capital of China" because of its high reserves and production of gold. Intensive mining and smelting have taken place in this region since 595 A.D. (Liang et al., 2011; Yang and Zhou, 2000). Linglong gold mine and Jinchiling gold mine are the two largest gold deposits in this area (Fig. 1). Huge quantities of waste rock and tailings are now exposed to oxidizing water and air (Fig. S1a), causing weathering of sulfides. Lu et al. (1999) found that pyrite is ubiquitous in ore bodies of the Linglong gold mine.

AMD increases acidity and releases high amounts of $\mathrm{SO}_{4}^{2-}$, metals, and metalloids into surface water. In our earlier studies we found that the upper reach $(4.3-11.0 \mathrm{~km})$ of the Jiehe River was severely impacted by AMD; there was an abundance of heavy metals ( $\mathrm{As}, \mathrm{Cr}, \mathrm{Cu}, \mathrm{Zn}, \mathrm{Cd}$, and $\mathrm{Pb}$ ) in the surface water and stream sediment (Zhang et al., 2014). Heavy metals are released from contaminated stream sediment through mineral dissolution, surface desorption, and particle resuspension (Cai et al., 2015; Canovas et al., 2012; Santos Bermejo et al., 2003); this release of

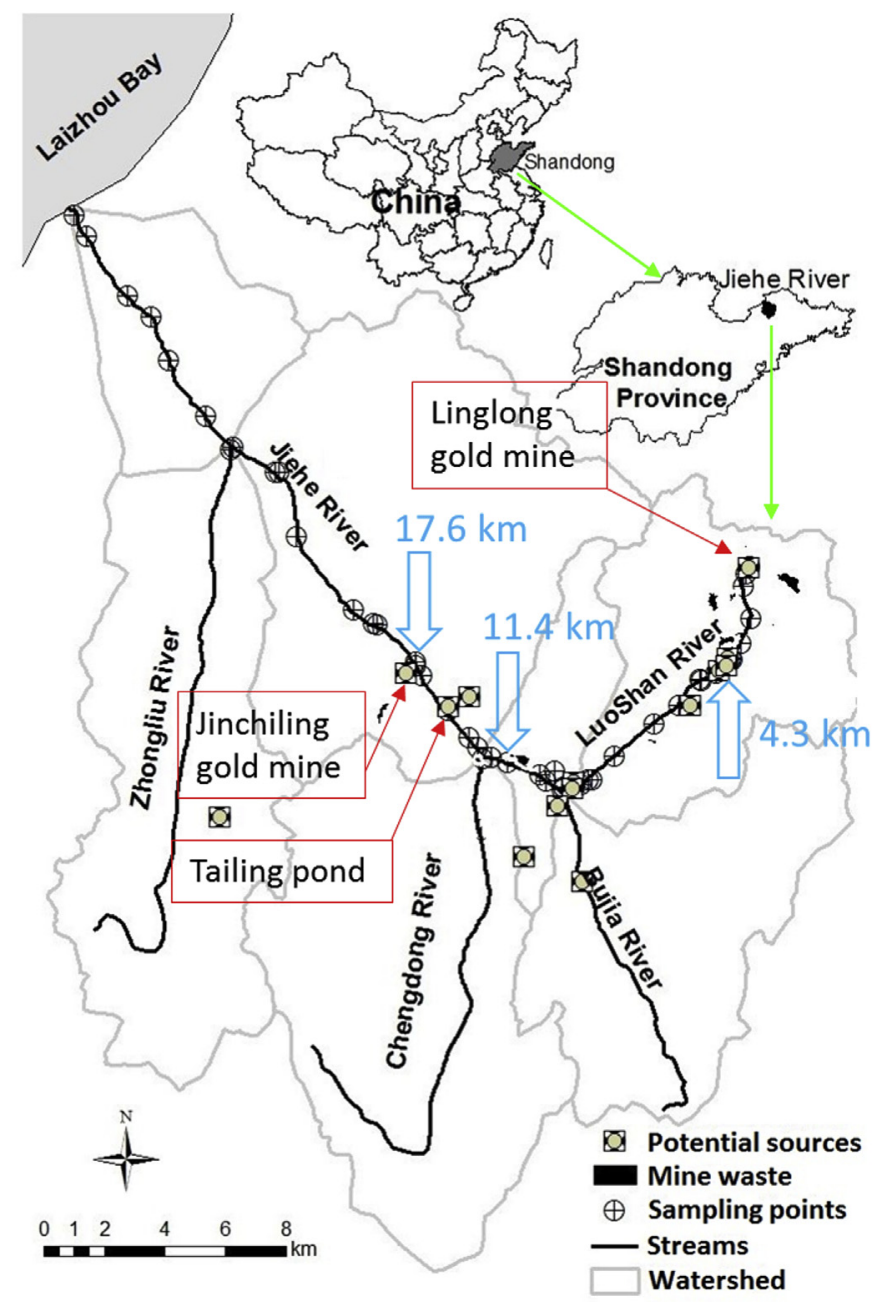

Fig. 1. Map showing the locations of sampling sites, potential pollution sources, and stream reaches in the Jiehe River watershed.

contaminants may cause long-term and increasingly serious pollution to the Jiehe River watershed. The information on geology and geochemical of the study area were introduced in our earlier studies. Detailed information about the study area can be found in Zhang et al. (2014) and Cai et al. (2015).

\subsection{Sampling procedure}

Thirty-eight samples were collected along the main stream of Jiehe River (37.5 km) in March 2015 (Fig. 1). During the sampling period, there were ongoing river engineering work in upstream which involves dredging and channelization. Temperature, $\mathrm{pH}$, electrical conductivity (EC), and redox potential (Eh) were measured in the field during water sampling using a calibrated multi-parameter handheld water quality meter (556MPS, YSI, Yellow Springs, Ohio, USA). Water samples were carefully collected from the stream using a $500-\mathrm{mL}$ plastic bucket without disturbing the bottom sediment. A portion of each sample was filtered immediately in the field through $0.45 \mu \mathrm{m}$ Whatman syringe filters for the analysis of "dissolved" constituents (filtered forms); the rest was used for the analysis of total elements. Both filtered and nonfiltered samples were acidified in the field to a $\mathrm{pH}<2$ with ultrapure $\mathrm{HNO}_{3}$ and then stored in the dark at $4{ }^{\circ} \mathrm{C}$ in polyethylene bottles until analysis. Sub-samples collected for determining As species in filtered water were not acidified; they were stored and 
refrigerated in brown glass bottles in the dark until analysis.

Particle size of minerals affects As distribution. For example, Serrano et al. (2015) found that up to one-third of total As was associated with dispersible colloidal fraction $(10-1000 \mathrm{~nm})$; Macgregor et al. (2015) found that Sb was predominantly present in truly dissolved $(<3 \mathrm{~nm})$ forms whilst $\mathrm{As}$ and $\mathrm{Pb}$ were more commonly associated with Fe-rich/organic colloids ( $>3 \mathrm{~nm}$ ); and Gomez-Gonzalez et al. (2016) found that As and Fe concentration maxima appeared at 143, 115, and $136 \mathrm{~nm}$ for the colloidsuspension of mining-affected soils. As such, three fractions were designated in this study as follows: (i) particulate fraction (>450 nm), obtained with $0.45 \mu \mathrm{m}$ filters; (ii) colloidal fraction (7-450 nm), separated from the $0.45 \mu \mathrm{m}$-filtrate by ultrafiltration using $30 \mathrm{kDa}(7 \mathrm{~nm})$ membranes (Millipore Corp., Billerica, MA, USA) at $4000 \times \mathrm{g}(60 \mathrm{~min})$; and (iii) truely dissolved fraction, obtained after passing through $7 \mathrm{~nm}$ ultrafiltration membranes.

\subsection{Analytical determinations}

Total (unfiltered), filtered $(<0.45 \mu \mathrm{m})$, and truely dissolved $(<7 \mathrm{~nm})$ concentrations of As and Fe were determined with an Inductively Coupled Plasma-Mass Spectrometer (ICP-MS, ELAN DRC II, Perkin Elmer SCIEX, Waltham, MA, USA). The analytical errors (measured as a standard deviation) were consistently less than $5 \%$; the differences between field duplicates were consistently within the range of certified values. The particulate fraction of a trace element was calculated as the difference between unfiltered and filtered concentrations. The species of As [As(III), As(V), MMA, and DMA] were analyzed using a High Performance Liquid Chromatography-Inductively Coupled Plasma-Mass Spectrometer (HPLC-ICP-MS, PE NexION 300X, Perkin Elmer SCIEX). Rigorous quality assurance and quality control measures were employed, e.g., the use of blanks, duplicates, and reference materials.

$\mathrm{Fe}(\mathrm{II})$ was determined using a colorimetric method at $510 \mathrm{~nm}$ following complexation with 1,10-phenanthroline. $\mathrm{Fe}(\mathrm{III})$ was calculated as the difference between the filtered Fe and ferrous Fe (Canovas et al., 2007). The detection limit was $0.2 \mathrm{mg} \mathrm{L}^{-1}$, and the precision was greater than $5 \%$. The microscopic morphology and elemental composition (weight percentage, wt\%) of the suspended particulate matter remained on $0.45 \mu \mathrm{m}$ membrane filters were obtained with a scanning electron microscope-energy dispersive spectrometer (S-4800, Hitachi, Tokyo, Japan).

\subsection{Modeling with Visual MinteQ}

The speciation of As and Fe in filtered samples were calculated using a geochemical equilibrium modeling program, Visual MinteQ version 3.0 (http://vminteq.lwr.kth.se/). The observed distributions of colloidal and true dissolved As and Fe were compared with their theoretical equilibrium distributions. Fe was entered as $\mathrm{Fe}(\mathrm{III})$ and $\mathrm{Fe}(\mathrm{II})$ using the observed values. $\mathrm{Fe}$ (III) was allowed to precipitate when the solubility of ferrihydrite $\left[\mathrm{Fe}(\mathrm{OH})_{3}\right.$, with a logKs value of 3.2] was exceeded in the upstream reach $(0-11.4 \mathrm{~km})$. Fe(III) was not allowed to precipitate in the downstream reach $(11.4-37.5 \mathrm{~km})$ because the filtered Fe that we observed in water samples existed mainly in true dissolved forms.

Along the sampled stream reach $(0-37.5 \mathrm{~km})$, arsenic was entered as As(III), and filtered concentration of As was used. We assumed that $\mathrm{As}(\mathrm{III})$ was not oxidized to $\mathrm{As}(\mathrm{V})$ in the upstream reach $(0-11.4 \mathrm{~km})$ because almost all of the observed As was As(III) in the filtered samples, as determined with HPLC-ICP-MS. In the downstream reach $(11.4-37.5 \mathrm{~km})$, the redox couples of $\mathrm{H}_{3} \mathrm{AsO}_{3} /$ $\mathrm{H}_{3} \mathrm{AsO}_{4}$ was adopted because the vast majority of $\mathrm{As}$ was $\mathrm{As}(\mathrm{V})$ in the filtered samples. The reduction of $\mathrm{Fe}(\mathrm{III})$ to $\mathrm{Fe}(\mathrm{II})$ was not allowed. Surface complexation modeling HFO (Dzombak and
Morel, 1990) was used to simulate the adsorption reactions, and the temperature was set to $15^{\circ} \mathrm{C}$. The solid concentration was set to $0.02 \mathrm{~g} \mathrm{~L}^{-1}$ for the upstream reach and $0.0001 \mathrm{~g} \mathrm{~L}^{-1}$ for the downstream reach according to the geochemistry characteristics of the river water. The observed $\mathrm{pH}$ and Eh values of each sampling site were used in the modelling.

\section{Results and discussion}

\subsection{Physicochemical conditions of stream water}

Fig. S2 (Supplementary Material) shows the spatial distributions of $\mathrm{pH}, \mathrm{EC}$, and Eh along the main stream of the Jiehe River. Briefly, field-measured $\mathrm{pH}$ ranged between 2.7 and 8.2 with a median of 6.7. The lower $\mathrm{pH}$ in the stream reach $(0-2.0 \mathrm{~km})$ was caused by wastewater discharge from the Linglong gold mine (Fig. 1). The lower $\mathrm{pH}$ in the midstream reach $(13-16 \mathrm{~km})$ was caused by weathering of tailings from a tailing pond and wastewater discharge from a smelting factory. The rest of the stream had a circum-neutral $\mathrm{pH}$, and the maximum $\mathrm{pH}$ values were found at the lower reach where stone processing plants have been using industrial alkali as a cooling fluid in the production.

EC on the main stream varied between 1.2 and $14.6 \mathrm{mS} \mathrm{cm}^{-1}$ with a median of $4.5 \mathrm{mS} \mathrm{cm}^{-1}$. The values varied intensely along the stream reach, which might be related to the water $\mathrm{pH}$ (Fig. S3), especially in the stream reach $(13-16 \mathrm{~km})$. The Eh values fluctuated strongly along the sampled stream reach from 14.9 to $482.3 \mathrm{mV}$ with a median of $189.6 \mathrm{mV}$ (Fig. S3). Higher Eh values were measured when the $\mathrm{pH}$ values were lower. The variation of $\mathrm{pH}, \mathrm{EC}$ and Eh along the Jiehe river indicates the effects of gold mining and smelting factory on water chemistry. This result is consistent with earlier studies about AMD in mining areas such as the Iberian Pyrite Belt (SW Spain) (Sarmiento et al., 2009, 2012). The two reaches with higher Eh values can be attributed to the different AMD generation sources; the values observed from $25 \mathrm{~km}$ to the lower reach of $37.5 \mathrm{~km}$ were maintained at around $200 \mathrm{mV}$.

\subsection{Occurrence of As and Fe}

Fig. 2 illustrates the spatial distribution of particulate and filtered As and Fe along the main stream of Jiehe River. There were two distinct sources of As and Fe at $4.3 \mathrm{~km}$ with abundant of waste rocks in the river bed and $17.6 \mathrm{~km}$ contaminated by wastewater discharge from the Jichiling gold mine along the main river stream; these results are consistent with our earlier study (Zhang et al., 2014). High concentrations of the two elements were observed in both filtered and particulate forms in most of the water samples (Fig. 2). The total concentration of As was in the range of $1.0-719 \mu \mathrm{g} \mathrm{L}^{-1}$ with a median concentration of $140 \mu \mathrm{g} \mathrm{L}^{-1}$, which exceeded the limit for the fifth class water $\left(100 \mu \mathrm{g} \mathrm{L}^{-1}\right)$ in Chinese regulations (SEPA, 2002). The total concentration of Fe was in the range of $0.4-68.2 \mathrm{mg} \mathrm{L}^{-1}$ with a median concentration of $15.0 \mathrm{mg} \mathrm{L}^{-1}$.

In water samples near the pollutant source at $4.3-5.0 \mathrm{~km}$, arsenic occurred mostly in particulate forms $\left(162-438 \mu \mathrm{g} \mathrm{L}^{-1}\right)$, and Fe occurred mostly in filtered forms (30.6-51.7 $\mathrm{mg} \mathrm{L}^{-1}$ ) (Fig. 2). The particulate to total As ratio was $48-84 \%$, and the percentages of filtered to total Fe was 65-90\%. High concentrations of particulate As was linked to ubiquitous presence of pyrite and some As-bearing minerals in the river bed at $4.3-5.0 \mathrm{~km}$ (Figs. S1a and b). Further down $5 \mathrm{~km}$, arsenic decreased quickly to a lower level, meeting the requirements of the Chinese environmental quality standards (SEPA, 2002). This observation is different from our previous finding that As can be transported a long distance of more than $11 \mathrm{~km}$ in the Jiehe River (Zhang et al., 2014), which might relate to 

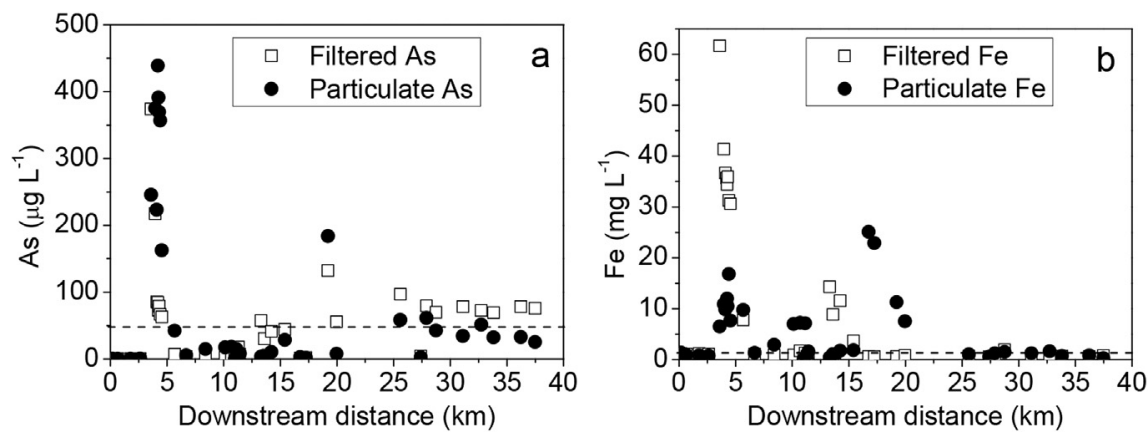

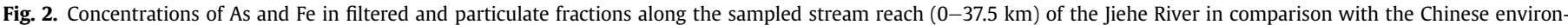

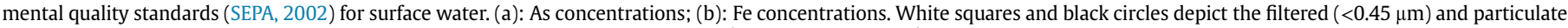
forms $(>0.45 \mu \mathrm{m})$, respectively; dash lines depict the Chinese standards ( $50 \mu \mathrm{g} \mathrm{L}^{-1}$ for As and $1 \mathrm{mg} \mathrm{L}^{-1}$ for Fe).

the river engineering projects from the downstream distance of $5.0 \mathrm{~km}$ (Figs. S1a and b). Arsenic can be easily sorbed or precipitated onto disturbed soil on Fe-oxyhydroxides-rich river bed produced from long-time weathering of waste rocks (Casiot et al., 2003; Bednar et al., 2005). The increase in filtered As and $\mathrm{Fe}$ at $13-16 \mathrm{~km}$ is caused by release of low-pH AMD that (Fig. S2) flowed into the stream reach from the tailings pond.

At a downstream distance of $17.6 \mathrm{~km}$ to the stream outlet $(37.5 \mathrm{~km})$, arsenic was present mostly in filtered forms with a filtered/total ratio of $42-88 \%$. Total As concentration ranged from 3.9 to $316.4 \mu \mathrm{g} \mathrm{L}^{-1}$ with a median value of $113.2 \mu \mathrm{g} \mathrm{L}^{-1}$, which was much higher than that reported in our recent study-50 $\mu \mathrm{g} \mathrm{L}^{-1}$ (Zhang et al., 2014). This higher value may have been caused by river dredging (Figs. S1c and d), which stirred the stream sediment and released abundant As into the water when the contaminated sediment was fully mixed with mildly alkaline water (Cai et al., 2015). Water with a high As concentration flowing into Laizhou Bay poses an ecological risk to marine organisms and humans. Runkel et al. (2009) found that, after remediation, the concentrations of $\mathrm{Al}, \mathrm{Cd}, \mathrm{Cu}, \mathrm{Pb}$, and $\mathrm{Zn}$ in stream water still exceeded State of Colorado aquatic-life standards over the entire study reach. Therefore, the release of As and other toxic elements from contaminated sediments or tailings must be considered before and after river engineering projects. Dredging and channelization of river way have caused variation in release and retention of heavy metals and thus changed the distribution and speciation of As. The remediation design and implementation need to take into account the geochemical characteristics of the contaminated water and sediments.

The observed and modeled concentrations of colloidal and truely dissolved As and Fe along the stream reach $(0-37.5 \mathrm{~km})$ are shown in Fig. 3. Colloidal As and Fe were the main species in water samples collected from the upstream reach $(0-11.4 \mathrm{~km})$, whereas in the downstream reach $(11.4-23.3 \mathrm{~km})$ As and Fe mainly existed in truely dissolved species. Geochemical equilibrium modeling successfully simulated the chemical speciation of Fe and As in filtered water samples along the stream reach (Fig. 3). There were high correlation coefficients between measured and modeled values of As and Fe. The correlation coefficients of true dissolved As and Fe were 0.99 and 0.97 . The correlation coefficients of colloidal As and Fe were both 0.99. A variable but important fraction of As may be bound to nanoparticulate ferrihydrite in the dispersible colloidal fraction that can be released from contaminated soils and transported downstream in natural systems (Serrano et al., 2015). Ferrihydrite is the dominant As-bearing colloidal phase in surface runoff from mining-affected soils (Gomez-Gonzalez et al., 2016). In the upstream reach $(0-11.4 \mathrm{~km})$ of the Jiehe River, the filtered As might be strongly associated with ferrihydrite colloids that were generated by the oxidation of pyrite among various minerals. In the downstream reach $(11.4-37.5 \mathrm{~km})$, there were low concentrations of Fe; the filtered As might be released from the stream sediment that was contaminated by long-term gold mining.

Fig. 4 shows the relationship between different species of As and Fe along the stream reach. A good correlation was found between total As and total Fe in the upstream reach (Fig. $4 a, R^{2}=0.93$ ), but not in the downstream reach (Fig. 4b). This may be explained by the large variations and different geochemical characteristics of As along the main stream reach. In the upstream reach abundant waste rocks and tailings in river channel were exposed to oxygen in water and air, and iron-bearing minerals provided the carriers for As transport. An excellent correlation between the filtered As and Fe in the stream reach of $0-11.4 \mathrm{~km}\left(\mathrm{R}^{2}=0.94\right.$, Fig. $\left.4 \mathrm{c}\right)$ suggests the
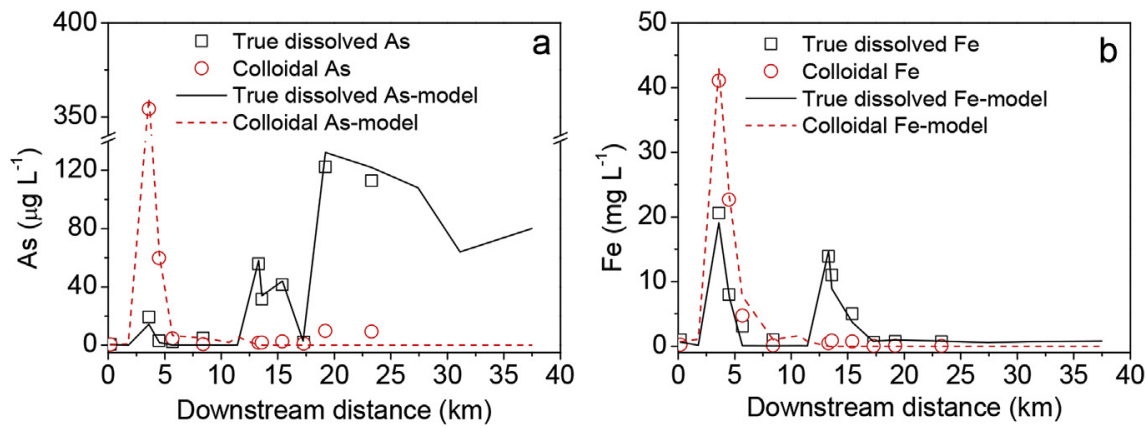

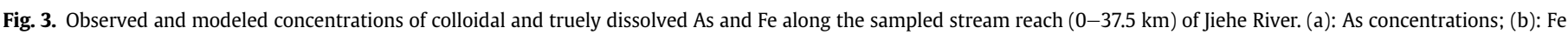

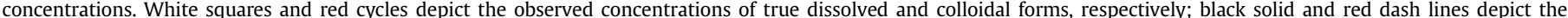

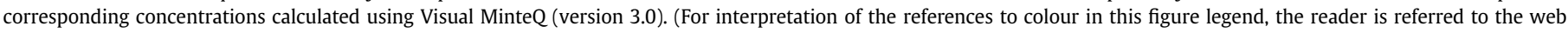
version of this article.) 

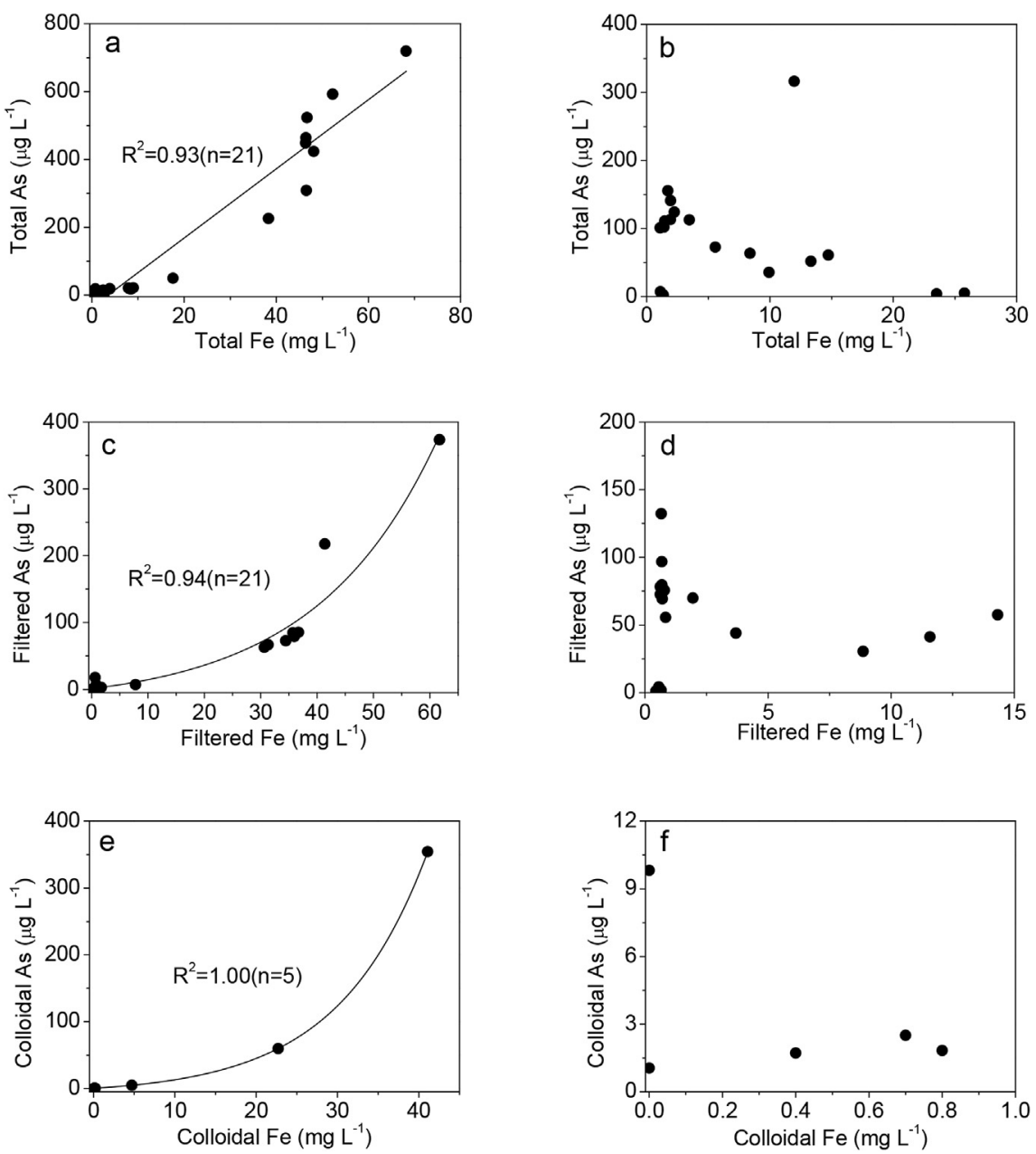

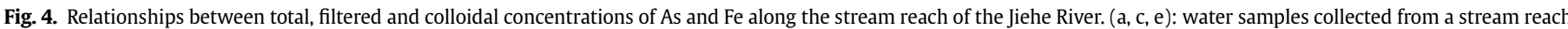
of $0-11.4 \mathrm{~km}$; (b, d, f): water samples collected from a stream reach of $13.3-37.5 \mathrm{~km}$.

existence of As in colloids, mainly arsenic bearing iron minerals. This is consistent with the model result in Fig. 3. Moreover, the excellent correlation between colloidal As and colloidal $\mathrm{Fe}$ in stream reach of $0-11.4 \mathrm{~km}$ (Fig. $4 \mathrm{e}$ ) indicates that As-bearing iron minerals were the main filtered forms in the upstream reach. This colloidal As can be transported a long distance in the Jiehe River, as demonstrated by our earlier study (Zhang et al., 2014). Colloidassociated transport in stream water is an important factor that influences the environmental and geochemical process such as adsorption-desorption, precipitation-dissolution, oxidationreduction, of metals and metalloids (Dahlqvist et al., 2007; Neubauer et al., 2013).

SEM images of suspended particulates (Fig. 5a and b) show a cluster of small radial fiber structure particles $(<50 \mathrm{~nm})$, which might be ferrihydrite coating the surface of larger particles (Gomez-Gonzalez et al., 2014). Fig. 5c and d reveal the presence of numerous rod-shaped particles (approximately 20-30 $\mu \mathrm{m}$ ) with characteristics similar to goethite $[\mathrm{FeO}(\mathrm{OH})]$ (Liu et al., 2014). Table 1 showed the elemental composition of the suspended particulate matter on two filter membranes (M1 and M2). The high content of Fe (27.97 wt\%, 29.79 wt\%) and As (1.29 wt\%, $1.48 w t \%)$ is consistent with the results in water samples. This suggests that the particles in SEM images (Fig. 5) contain high amounts of ferrihydrite and goethite, resulting in abundant As adsorbed on their surfaces. According to our data now, it is still hard to estimate which mineral (ferrihydrite or goethite) was more likely to be the
As host here. Ferrihydrite is thermodynamically metastable and can be transformed with aging to the more crystalline productsgoethite and hematite $\left(\mathrm{Fe}_{2} \mathrm{O}_{3}\right)$ (Mitsunobu et al., 2013). We suggest three steps in the geochemical reaction process of As in this study area: (1) the oxidation of pyrite and As-bearing minerals released As and Fe into stream water; (2) dissolved Fe easily precipitated when the solubility of ferrihydrite was exceeded under the conditions of this study; (3) under wet-dry cycling conditions, dehydration of ferrihydrite generated goethite and hematite. The As released by As-bearing minerals was adsorbed or coprecipitated again by ferrihydrite, goethite, and hematite. Furthermore, some primary mineral pyrite might be still in the suspended particulate matter as it contains high amount of sulfur (2.82 wt\%, $2.68 \mathrm{wt} \%$ ) (Table 1). With abundant of waste rock in the upstream river bed in the wet-dry alternate environmental conditions, goethite and hematite formed and act as As sinks. I think the most direct and effective way to prevent As remobilization from these secondary As sinks is clear away the waste rock in the river bed and then centralized disposal.

\subsection{As and Fe species in filtered fractions}

In the studied samples, inorganic As species of up to $128 \mu \mathrm{g} \mathrm{L}^{-1}$ were detected, whereas MMA was below the detection limit. DMA was only present in seven of 25 samples, possibly because the biomethylation of inorganic As was facilitated by microorganisms 

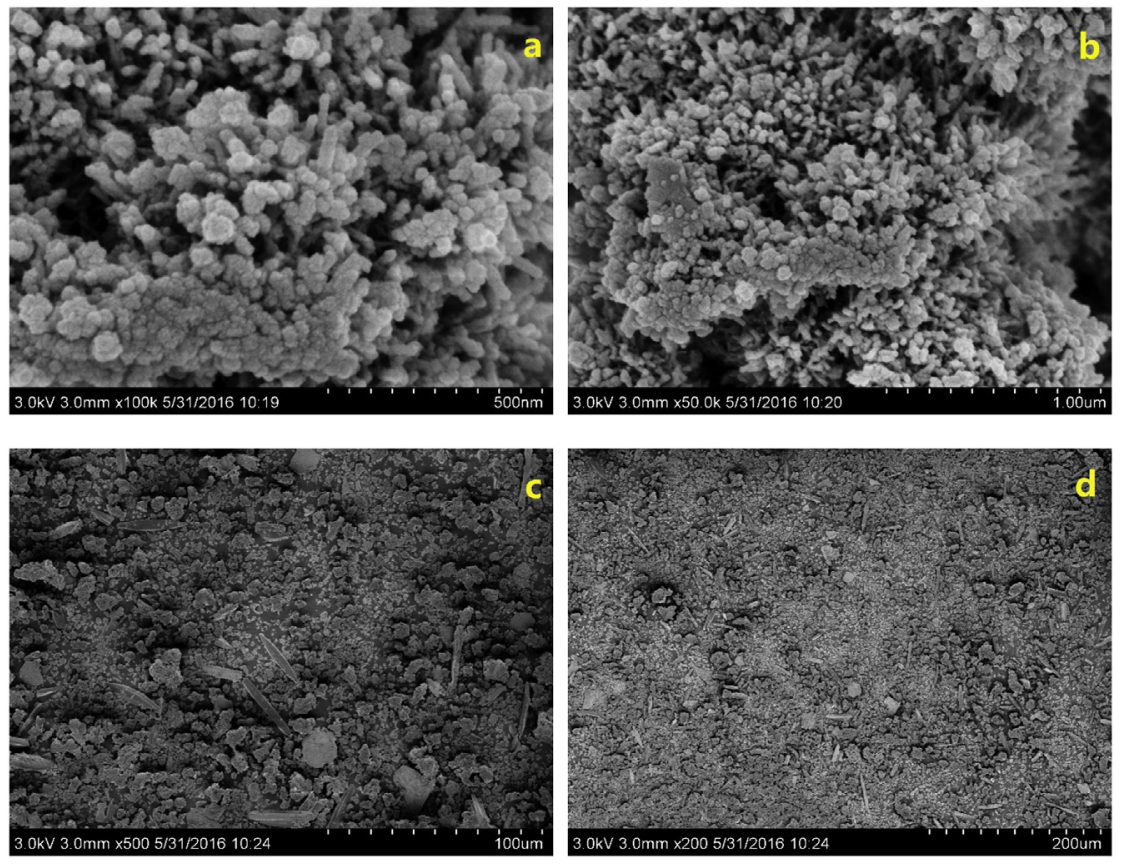

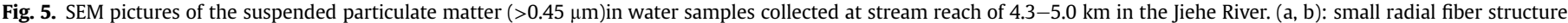
particles (<50 nm); (c, d): numerous rod-shaped particles (approximately 20-30 $\mu \mathrm{m}$ ).

Table 1

Elemental compositions (weight percentage, wt\%) of the suspended particulate matter in water samples filtered by two $0.45 \mu \mathrm{m}$ filter membranes (M1 and M2) at stream reach of $4.3-5.0 \mathrm{~km}$ in the Jiehe River.

\begin{tabular}{lllllllllll}
\hline Element & $\mathrm{C}$ & $\mathrm{O}$ & $\mathrm{Na}$ & $\mathrm{Al}$ & $\mathrm{Si}$ & $\mathrm{S}$ & $\mathrm{K}$ & $\mathrm{Ca}$ & $\mathrm{Fe}$ & $\mathrm{As}$ \\
\hline M1 & 15.16 & 44.77 & 0.29 & 1.70 & 3.29 & 2.82 & 0.38 & 0.32 & 29.79 & 1.48 \\
M2 & 13.20 & 44.46 & 0.43 & 2.81 & 5.83 & 2.68 & 0.70 & 0.36 & 27.97 & 1.29 \\
\hline
\end{tabular}

(Cullen and Reimer, 1989) present in AMD (López-Rodas et al., 2008). This is consistent with previous findings that the inorganic species of $\mathrm{As}[\mathrm{As}(\mathrm{III})$ and $\mathrm{As}(\mathrm{V})]$ were predominant (Sarmiento et al., 2009), and the methylated species were almost absent (SánchezRodas et al., 2005, 2006) in water samples from AMDcontaminated mining areas. Fig. 6 shows the observed and modeled concentrations of As and Fe species in filtered fractions along the sampled stream reach $(0-37.5 \mathrm{~km})$. The concentrations of As in filtered samples (unacidified) were much lower (Fig. 6a) than those in filtered samples acidified to $\mathrm{pH} 2$ (Fig. 2a) at the stream reach of $0-11.4 \mathrm{~km}$. This is because the lower $\mathrm{pH}$ in acidified samples prevented As(III) oxidation and consequent adsorption onto, or coprecipitaion with, Fe-rich colloids before analysis
(Sánchez-Rodas et al., 2006). At a river distance of $11.4 \mathrm{~km}$ to the stream outlet, As concentrations in filtered samples (unacidified, Fig. 6a) were in consistent with those of acidified samples (Fig. 2a), indicating As was mostly present in true dissolved forms in the downstream reach, which is consistent with Fig. 3. Therefore, we postulate that As in the water samples originated from a) the weathering of waste rocks under wet-dry alternate conditions in the upstream river bed; and b) the release from sediment contaminated by long-term waste water discharge from Jichiling mine. Arsenic from the two sources exhibited different geochemical characteristics as they were under different hydrogeochemical conditions.

A high concentration of $\mathrm{Fe}(\mathrm{II})\left(7.6-19.2 \mathrm{mg} \mathrm{L}^{-1}\right)$ was detected under the condition of the stream water (Fig. S2); the concentration of Fe(II) quickly decreased (Fig. 6b). Under AMD conditions, Fe(II) is easily oxidized and transformed into ferrihydrite when the acidity is neutralized (Bigham et al., 1990). With increasing distance from the emergence point $(4.3 \mathrm{~km})$, filtered $\mathrm{As}(\mathrm{III})$ concentrations dropped to low levels through sorption on hydrous ferric oxides. $\mathrm{As}(\mathrm{V})$ was the predominant species at a river distance of $11.4 \mathrm{~km}$ to the stream outlet (Fig. 6a).
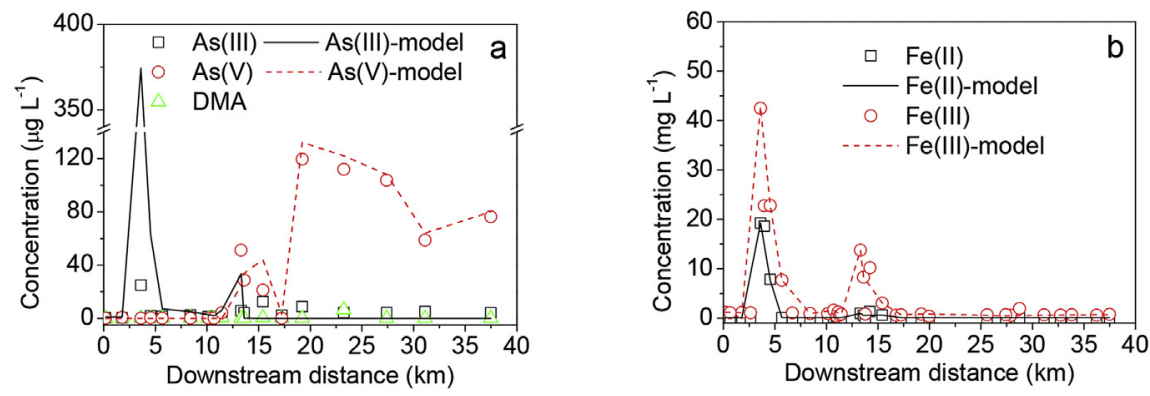

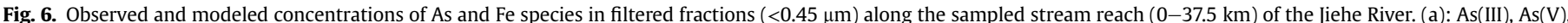

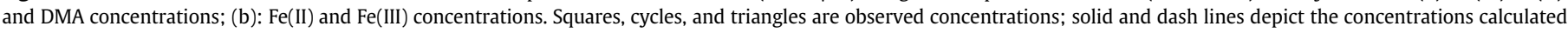
using Visual MinteQ (version 3.0). 
The geochemical equilibrium model successfully simulated the Fe species along the sampled stream reach $(0-37.5 \mathrm{~km})$ and the As species along the downstream reach (11.4-37.5 km). However, the model did not simulate the As species well in the upstream reach $(0-11.4 \mathrm{~km})$ because the samples collected for As species analysis were not acidified to a $\mathrm{pH}<2$; consequently, arsenic was mainly present in colloidal form. The geochemical equilibrium calculation revealed that the As adsorbed or co-precipitated on stream sediment may be easily released under the environmental conditions of the downstream reach $(11.4-37.5 \mathrm{~km})$. Thus, preventing this secondary pollution of As in the Jiehe River is of importance to environmental management.

\section{Conclusion}

This study was performed along $37.5 \mathrm{~km}$ reach of the Jiehe River impacted by gold mining. Two distinct point sources of As and Fe were found at 4.3 and $11.4-17.6 \mathrm{~km}$ along the main river stream, and As was also found to be released from the river sediments in the downstream reach $(17.6-37.5 \mathrm{~km})$. In the upstream reach $(0-11.4 \mathrm{~km}), \mathrm{As}(\mathrm{III})$ was the main As species, produced by the oxidation of waste rocks containing As-bearing minerals (e.g., arsenian pyrite or arsenopyrite), and As mainly existed as colloidal form in the filtered fractions of water samples. Further investigations is warranted to determine the primary As contents in ore or waste rock and the mineral composition of the ore or waste rock as it would help us to understand the primary As source function. The SEM-EDS analysis showed high contents of Fe (27.97 wt\%, $29.79 \mathrm{wt} \%$ ) and As (1.29 wt\%, $1.48 \mathrm{wt} \%$ ) in the suspended particulate matter, and arsenic was mainly adsorbed on ferrihydrite, goethite, and hematite. In the downstream reach (11.4-37.5 km), As(V) was the predominant species in the filtered fractions of water samples and As was mostly present in truely dissolved forms. Visual MinteQ model revealed that the As adsorbed on, or co-precipitated with, stream sediment can be easily released under the environmental conditions of the downstream reach $(11.4-37.5 \mathrm{~km})$. Colloidal As generated by the oxidation of waste rocks and As released from contaminated sediment can be transported over long distances even to the Laizhou Bay. Overall, As-rich mine wastes along the upstream reach and the contaminated sediment in the downstream reach are the sources of As pollution in the Jiehe River. The results provided essential information for develop remediation design and implementation in mining impacted streams.

\section{Acknowledgements}

This work was financially supported by the National Natural Science Foundation of China (41271506, 41230858, and 21607002), the Key Research Program of the Chinese Academy of Sciences (KZZD-EW-14). Dr. Hua Zhang was supported by the Recruitment Program of Global Young Experts (1000Plan).

\section{Appendix A. Supplementary data}

Supplementary data related to this article can be found at http:// dx.doi.org/10.1016/j.apgeochem.2017.07.001.

\section{References}

Baeyens, W., Brauwerea, A., Briona, N., De Gietera, M., Leermakersa, M., 2007. Arsenic speciation in the river zenne, Belgium. Sci. Total Environ. 384, 409-419.

Basu, A., Schreiber, M.E., 2013. Arsenic release from arsenopyrite weathering: insights from sequential extraction and microscopic studies. J. Hazard. Mater 262, 896-904.

Bednar, A.J., Garbarino, J.R., Ranville, J.F., Wildeman, T.R., 2005. Effects of iron on arsenic speciation and redox chemistry in acid mine water. J. Geochem. Explor 85, 55-62.

Bigham, J.M., Schwertmann, U., Carlson, L., Murad, E., 1990. A poorly crystallized oxyhydroxysulfate of iron formed by bacterial oxidation of Fe(II) in acid mine waters. Geochim. Cosmochim. Acta 54, 2743-2758.

Cai, Y., Mi, Y., Yu, J., Zhang, H., 2015. Arsenic speciation and kinetic release simulation of stream sediment contaminated by gold mining. J. Soil Sediment. 16 (3), $1121-1129$.

Canovas, C.R., Olias, M., Sarmiento, A.M., Nieto, J.M., Galvan, L., 2012. Pollutant transport processes in the Odiel River (SW Spain) during rain events. Water Resour. Res. 48 (6), W06508.

Canovas, C.R., Olias, M., Nieto, J.M., Sarmiento, A.M., Ceron, J.C., 2007. Hydrogeochemical characteristics of the Tinto and Odiel Rivers (SW Spain). Factors controlling metal contents. Sci. Total Environ. 373 (1), 363-382.

Carroll, S., O'Day, P.A., Esser, B., Randall, S., 2002. Speciation and fate of trace metals in estuarine sediments under reduced and oxidized conditions, Seaplane Lagoon, Alameda Naval Air Station (USA). Geochem. Trans. 3 (10), 81-101.

Casiot, C., Leblanc, M., Bruneel, O., Personne, J.C., Koffi, K., Elbaz-Poulichet, F., 2003 Geochemical processes controlling the formation of As-rich waters within a tailings impoundment (Carnoulès, France). Aquat. Geochem 9, 273-290.

Cheng, H., Hu, Y., Luo, J., Xu, B., Zhao, J., 2009. Geochemical processes controlling fate and transport of arsenic in acid mine drainage (AMD) and natural systems. J. Hazard. Mater 165 (1-3), 13-26.

Cullen, W.R., Reimer, K.J., 1989. Arsenic speciation in the environment. Chem. Rev. 89, 713-764.

Dahlqvist, R., Andersson, K., Ingri, J., Larsson, T., Stolpe, B., Turner, D., 2007. Temporal variations of colloidal carrier phases and associated trace elements in a boreal river. Geochim. Cosmochim. Acta 71 (22), 5339-5354.

Desbarats, A.J., Parsons, M.B., Percival, J.B., 2015. Arsenic mobility in mildly alkaline drainage from an orogenic lode gold deposit, Bralorne mine, British Columbia. Appl. Geochem 57, 45-54.

Dzombak, D.A., Morel, F., 1990. Surface Complexation Modeling: Hydrous Ferric Oxide. Wiley, New York.

Equeenuddin, S.M., Tripathy, S., Sahoo, P.K., Panigrahi, M.K., 2013. Metal behavior in sediment associated with acid mine drainage stream: role of $\mathrm{pH}$. J. Geochem. Explor 124, 230-237.

Frau, F., Addari, D., Atzei, D., Biddau, R., Cidu, R., Rossi, A., 2010. Influence of major anions on $\mathrm{As}(\mathrm{V})$ adsorption by synthetic 2-line ferrihydrite. Kinetic investigation and XPS study of the competitive effect of bicarbonate. Water Air Soil Pollut. 205, 25-41.

Fritzsche, A., Rennert, T., Totsche, K.U., 2011. Arsenic strongly associates with ferrihydrite colloids formed in a soil effluent. Environ. Pollut. 159 (5), 1398-1405.

Gomez-Gonzalez, M.A., Serrano, S., Laborda, F., Garrido, F., 2014. Spread and partitioning of arsenic in soils from a mine waste site in Madrid province (Spain). Sci. Total Environ. 500-501, 23-33.

Gomez-Gonzalez, M.A., Voegelin, A., Garcia-Guinea, J., Bolea, E., Laborda, F. Garrido, F., 2016. Colloidal mobilization of arsenic from mining-affected soils by surface runoff. Chemosphere 144, 1123-1131.

Liang, N., Yang, L.Y., Dai, J.R., Pang, X.G., 2011. Heavy metal pollution in surface water of Linglong gold mining area, China. 2011 3rd international conference on environmental science and information application technology esiat, vol. 10. Pt A, Procedia Environ. Sci. Elsevier Science Bv, Amsterdam, pp 914-917.

Linge, K.H., 2008. Methods for investigating trace element binding in sediments. Crit. Rev. Environ. Sci. Technol. 38, 165-196.

Liu, H., Chen, T., Frost, R.L., 2014. An overview of the role of goethite surfaces in the environment. Chemosphere 103,1-11.

López-Rodas, V., Marvá, F., Rouco, M., Costas, E., Flores-Moya, A., 2008. Adaptation of the chlorophycean Dictyosphaerium chlorelloides to stressful acidic, mine metal-rich waters as result of pre-selective mutations. Chemosphere 72 703-707.

Lu, H.Z., Guha, J., Fang, G.B., 1999. Characteristics of ore-forming fluid in Linglong gold mine, shandong, China. Geochim. (05) 421-437 (In Chinese).

Macgregor, K., MacKinnon, G., Farmer, J.G., Graham, M.C., 2015. Mobility of antimony, arsenic and lead at a former antimony mine, Glendinning, Scotland. Sci. Total Environ. 529, 213-222.

Mitsunobu, S., Muramatsu, C., Watanabe, K., Sakata, M., 2013. Behavior of Antimony(V) during the transformation of ferrihydrite and its environmental implications. Environ. Sci. Technol. 47 (17), 9660-9667.

Neubauer, E., Kammer, F., Knorr, K.H., Peiffer, S., Reichert, M., Hofmann, T., 2013. Colloid-associated export of arsenic in stream water during stormflow events. Chem. Geol. 352, 81-91.

Paikaray, S., 2015. Arsenic geochemistry of acid mine drainage. Mine Water Environ. 34 (2), 181-196.

Rauch, J.N., 2012. The present understanding of earth's global anthrobiogeochemical metal cycles. Mineral. Econ. 25, 7-15.

Runkel, R.L., Bencala, K.E., Kimball, B.A., Walton-Day, K., Verplanck, P.L., 2009 A comparison of pre- and post-remediation water quality, Mineral Creek, Colorado. Hydrol. Process. 23 (23), 3319-3333.

Sánchez-Rodas, D., Gómez-Ariza, J.L., Giráldez, I., Velasco, A., Morales, E., 2005 Arsenic speciation in river and estuarine waters from southwest Spain. Sci. Tota Environ. 345, 207-217.

Sánchez-Rodas, D., Oliveira, V., Sarmiento, A.M., Gómez-Ariza, J.L., Nieto, J.M., 2006. Preservation procedures for arsenic speciation in a stream affected by acid mine drainage in southwestern Spain. Anal. Bioanal. Chem. 384, 1594-1599.

Santos Bermejo, J.C., Beltran, R., Gomez Ariza, J.L., 2003. Spatial variations of heavy 
metals contamination in sediments from Odiel River (Southwest Spain). Environ. Int. 29 (1), 69-77.

Sarmiento, A.M., Caraballo, M.A., Sanchez-Rodas, D., Nieto, J.M., Parviainen, A., 2012. Dissolved and particulate metals and arsenic species mobility along a stream affected by Acid Mine Drainage in the Iberian Pyrite Belt (SW Spain). Appl. Geochem 27 (10), 1944-1952.

Sarmiento, A.M., Nieto, J.M., Casiot, C., Elbaz-Poulichet, F., Egal, M., 2009. Inorganic arsenic speciation at river basin scales: the tinto and odiel rivers in the iberian pyrite belt, SW Spain. Environ. Pollut. 157 (4), 1202-1209.

SEPA (State Environmental Protection Administration of China), 2002. National Environmental Quality Standards for Surface Water [GB3838-2002] (In Chinese).

Serrano, S., Gomez-Gonzalez, M.A., O'Day, P.A., Laborda, F., Bolea, E., Garrido, F. 2015. Arsenic speciation in the dispersible colloidal fraction of soils from a mine-impacted creek. J. Hazard. Mater 286, 30-40.
Shen, J., Li, S., Ma, G., Liu, Y., Yu, H., Liu, H., 2013. Typomorphic characteristics of pyrite from the Linglong gold deposit: its vertical variation and prospecting significance. Earth Sci. Front. 20 (3), 055-075.

Slowey, A.J., Johnson, S.B., Newville, M., Brown Jr., G.E., 2007. Speciation and colloid transport of arsenic from mine tailings. Appl. Geochem 22, 1884-1898.

Varol, M., 2011. Assessment of heavy metal contamination in sediments of the Tigris River (Turkey) using pollution indices and multivariate statistical techniques. J. Hazard. Mater 195, 355-364.

Yang. J.H., Zhou, X.H., 2000. The Rb-Sr isochron of ore and pyrite subsamples from Linglong gold deposit, Jiaodong Peninsula, eastern China and their geological significance. Chin. Sci. Bull. 45 (24), 2272-2277.

Zhang, H., Yu, J., Zhou, S., 2014. Spatial distribution of As, Cr, Pb, Cd, Cu, and $\mathrm{Zn}$ in the water and sediment of a river impacted by gold mining. Mine Water Environ. 33 (3), 206-216. 